\title{
Editorial:
}

\section{Debating Discourses, Practising Feminisms}

The essays in this issue demonstrate that any serious attempt to develop feminist practices is also an engagement with multiple discourses. By 'discourses' in this context we mean not just linguistic or textual issues, but dynamics and dialogics of substantive political debates. Each contribution is situated within complex and multi-layered terrains. Thus Sally Baden and Anne Marie Goetz map discursive conflicts at the United Nations Fourth World Conference on Women at Beijing; Purnima Mankekar locates one particular public debate in India as a site of political and cultural contestation; Laura Chernaik traces postmodern ethics in contemporary feminist science fiction; Sally R. Munt places the lesbian educator at the centre of debates around politics and pedagogy.

In pursuing each of these projects, the articles inevitably also interrogate myriad interrelated themes. 'Who needs (sex) when you can have (gender)?' is not just a report on the proceedings of the Beijing conference but also discusses the re-emergence of 'gender' and the subsequent decentring of 'women' in feminist theory in general and development policy in particular. It also reflects on tensions between activism and policymaking, and indeed on power relations between policy-makers in the 'north' and activists in the 'south'. In 'To whom does Ameena belong?' narratives of identity, citizenship and belonging reveal the inextricable links between notions of public and private, state, law and family, and 'childhood' as a barometer of gender, culture and political power. 'Pat Cadigan's Synners' examines a literary recasting of the relationship between nature, technology and what it means to be human in a postmodern moment, invoking problems of agency, difference and action. "I teach therefore I am" addresses the fraught politics of the academy - both its sexual politics and its professional politics - and in particular the ambivalent positions of lesbian teachers and lesbian students in institutions which both empower and disempower them.

Thus the essays presented here are wide-ranging in scope and very different in perspective and subject matter. However, their meeting points are at 
the borders delimiting the ethical, the political and the institutional. Borders between 'north' and 'south', 'sex' and 'gender', adulthood and childhood, lesbianism and heterosexuality, technology and nature ... and ultimately between debates and practices. But borders do not only demarcate separate territories: they also connect them.

Avtar Brah

Jayne O. Ifekwunigwe

Merl Storr

It has been brought to our attention that in the Summer 1995 issue of Feminist Review devoted to Ireland, one of the articles described Carol Coulter as a 'republican journalist'.

Dr Coulter has been a staff journalist with The Irish Times for over ten years, working in Belfast and London as well as Dublin, and her professionalism and impartiality have never been questioned. She is also the author of a number of books and essays on questions relating to women's rights, feminism, nationalism and identity. She has never been associated in any way with any republican organization.

We apologize to Dr Coulter for any distress caused. 